IIIIIIIIIIIIIIIIIIIIIIIIIIIII

ミニレビュー

|IIIIIIIIIIIIIIIIIIIIIIIIIIII

\title{
生物制御科学の未来を拓く一農薬科学の新展開への挑戦— ${ }^{*}$
}

ハダニにおける environmental RNAiの学理構築と防除への応用 $\ldots \ldots \ldots \ldots \ldots \ldots \ldots \ldots \ldots \ldots \ldots \ldots$ 鈴木丈詞 $(92)$

チャバネアオカメムシの発生量予測とビワ二重果実袋による防除効果

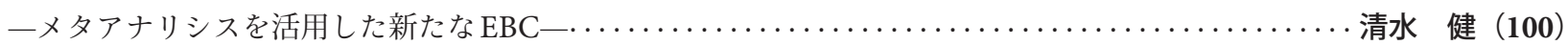

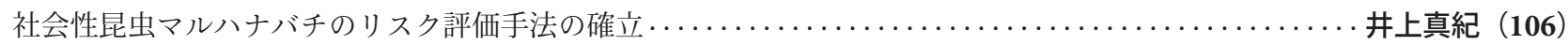

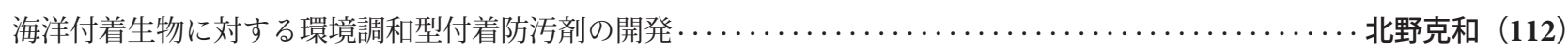

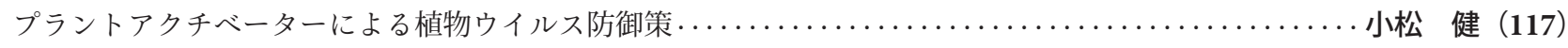

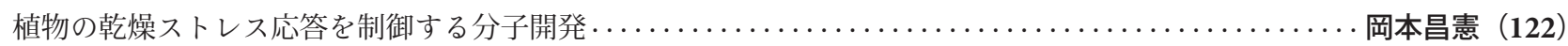

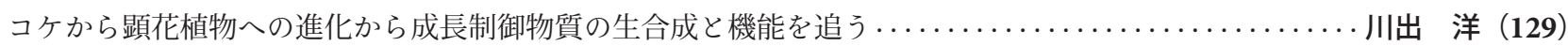

\section{オーガナイザー：豊田剛己（東京農工大学大学院生物システム応用科学府・農学研究院） \\ 有江 力*（東京農工大学大学院農学研究院）}

本ミニレビューは, 令和 3 年3月に東京農工大学（東京都 府中市) をベースにハイブリット開催した日本農薬学会第 46回大会の中で, 講演動画のオンデマンド配信とライブ双 方向配信による質疑で実施したシンポジウム「生物制御科学 の未来を拓く一農薬科学の新展開への挑戦—」でのご講演 の内容を7名のシンポジストにまとめていただいたものであ る. 新型コロナウイルス (SARS-CoV-2) 感染症COVID-19 の感染拡大が抑えられない中, 新たな形式で実施したシンポ ジウムであったが, 多くの参加者にご講演を視聴いただき, また，チャットやライブでの活発な質疑が行われた。

新型コロナウイルス感染症は, 人類の命に対する直接的脅 威であり, 世界的に甚大な影響を及ぼしている。, 一方, 植 物の病害・虫害・雑草害などは, 食料生産を通じて, 間接 的ながらも人類の命に大きな影響を及ぼしている. 奇しく も，2020年～2021年6月は，国際連合食糧農業機関（FAO） が主導する国際植物防疫年 (International Year of Plant Health, IYPH2020）にあたった.IYPH2020は,「国連が定 める持続的開発目標 (SDGs) のもと, 飢餓を終わらせ, 貧 困を減らし, 環境を保全し, 経済発展を促進するための植 物の健康の維持（植物保護）の重要性について, 世界的な認 識を高める」ことを目的にし, 社会啓蒙活動などが実施され

\footnotetext{
\#第46回大会シンポジウムを取りまとめた解説.

Opening the new era of pesticide science by studying bio-regulation and bio-interaction

*\% 183-8509 東京都府中市幸町 3-5-8

E-mail: arie@cc.tuat.ac.jp

(c) 日本農薬学会
}

た. 日本農薬学会第 46 回大会も農林水産省から, IYPH2020 のオフィシャルサポーターとして認定され, 大会を通じて植 物保護の重要性を社会に発信した．新型コロナウイルス感染 拡大状況下でも, 人類が食料の心配をさほどしないで済んで いるのはまさに食料生産と植物保護の貢献に依ることは間違 いない.

このような背景の中, 本シンポジウムは, 農薬科学分野に 関連する, 害虫, 海洋付着生物, 植物ウイルス, 植物等を対 象として, 生理学的解析, 共生関係の解析, 制御技術やメ力 ニズムに関する研究, ストレス応答, 生化学的解析など, 多 様な視点から研究されているシンポジストにご講演いただ き, 生物制御の新たな形や価值を社会に提案することにつな げたい,という第 46 回大会組織委員会メンバーの思いから 計画されたものである. 各シンポジストにお書きいただいた レビューを拝見すると, その目論見が見事に当たり, 大変興 味深いものになったと再度自負するところである.

シンポジストの先生方には, 大会において動画を事前に準 備いただき，さらにライブでの質疑にもご対応いただいたう えに, 本ミニレビューを快く執筆いただいたこと, 心ょり感 謝申し上げる。 